\title{
'Response of dual purpose barley (Hordeum vulgare L.) varieties, sowing dates and fertility levels in sub- humid southern plains of Rajasthan
}

\author{
Mahesh Kumar Choudhary, Mukesh Kumar Yadav* and P.C. Chaplot \\ Department of Agronomy, Rajasthan College of Agriculture, Maharana Pratap University of Agriculture and \\ Technology, Udaipur (Rajastahn) India \\ (Email : ymukesh029@gmail.com)
}

\begin{abstract}
Dual propose barley varieties RD 2715 and RD 2552 proved equally effective in improving growth parameters (plant height, total tillers $\mathrm{m}^{-1}$ row) Dry matter accumulation at and after green fodder cutting compared to variety RD 2035. Both varieties RD 2715 at par with RD 2552, took longer duration to attain 50\% heading and maturity, produced significantly higher number of effective tiller $\mathrm{m}^{-1}$ row, ear length, grain ear ${ }^{-1}$, grain weight ear-1 and tes weight, recorded significantly higher green fodder yield by 6.52 and $5.17 \mathrm{t} \mathrm{ha}^{-1}$ over RD 2035, respectively. Variety RD 2552 at par with RD 2715 produced higher grain, straw and biological yield over variety RD 2035. Influence of sowing time revealed that various yield attributes viz., effective tillers, ear length grains ear $^{-1}$, grain weight ear ${ }^{-1}$ and test weight were significantly improved under $15^{\text {th }}$ November sowing compared to successive delay in sowing by 10 days i.e. on $25^{\text {th }}$ November and $5^{\text {th }}$ December. The crop sown on $15^{\text {th }}$ November produced higher fodder, grain, straw and biological yield. Application of $75 \mathrm{~kg} \mathrm{~N}+25 \mathrm{~kg} \mathrm{P}_{2} \mathrm{O}_{5}$ ha $^{-1}$ to dual purpose barley crop significantly improved plant height, total tiller $\mathrm{m}^{-1}$ row and dry matter at accumulation at successive growth stages before, at and after green foddder cutting over application of $60 \mathrm{~kg} \mathrm{~N}+20 \mathrm{~kg} \mathrm{P}_{2} \mathrm{O}_{5}$ ha $^{-1}$. Significant improvement in yield attributes viz., effective tillers, ear length, grains ear ${ }^{-1}$, test weight and grain weight ear-1 over application of lower fertility level i.e. $60 \mathrm{~kg} \mathrm{~N}+20 \mathrm{~kg} \mathrm{P}_{2} \mathrm{O}_{5}$ ha $^{-1}$. The significant improvement in aforesaid yield attributes led to highest green fodder, grain and straw yield of $30.77,3.89$ and $6.68 \mathrm{tha}^{-1}$ under application of $75 \mathrm{~kg}$ $\mathrm{N}+25 \mathrm{~kg} \mathrm{P}_{2} \mathrm{O}_{5} \mathrm{ha}^{-1}$ as to compared 29.91,3.60 and $6.09 \mathrm{tha}^{-1}$ under $60 \mathrm{~kg} \mathrm{~N}+20 \mathrm{~kg} \mathrm{P}_{2} \mathrm{O}_{5} \mathrm{ha}^{-1}$, respectively. Variety RD 2552 fetched highest net returns of Rs. 78398 which was found at par RD 2715 with Rs. 76580, however both recorded significantly higher net returns by Rs. 15363 and 13545 ha $^{-1}$, respectively over RD 2035. The highest $\mathrm{B} / \mathrm{C}$ ratio of 3.84 was recorded with variety RD 2552 which was at par with RD 2715 with B/C ratio of 3.75 however both varieties recorded significantly higher B/C ratio over RD 2035 .

Key Words : Dual purpose barley, Sowing dates, Productivity, Fertility level, Fodder yield

View Point Article : Choudhary, Mahesh Kumar, Yadav, Mukesh Kumar and Chaplot, P.C. (2018). 'Response of dual purpose barley (Hordeum vulgare L.) varieties, sowing dates and fertility levels in sub- humid southern plains of Rajasthan. Internat. J. agric. Sci., 14 (2) : 318-326, DOI:10.15740/HAS/IJAS/14.2/318-326. Copyright@ 2018: Hind Agri-Horticultural Society.
\end{abstract}

Article History : Received : 05.03.2018; Revised : 21.04.2018; Accepted : 07.05.2018

\footnotetext{
* Author for correspondence:
} 